\title{
SMAD7 wt Allele
}

National Cancer Institute

\section{Source}

National Cancer Institute. SMAD7 wt Allele. NCI Thesaurus. Code C52404.

Human SMAD7 wild-type allele is located in the vicinity of 18q21.1 and is approximately $31 \mathrm{~kb}$ in length. This allele, which encodes mothers against decapentaplegic homolog 7 protein, is involved in the attenuation of tumor growth factor-beta type 1 receptor signal transduction. 